\title{
The Tobacco Control Coalition
}

Tobacco is the main contributor to three groups of disease: cancer, lung disease, and heart disease. Everywhere in the world, health charities fighting these illnesses became natural leaders in the field of tobacco control. The Netherlands is no exception. The Dutch Cancer Society, the Dutch Heart Foundation, and the Lung Foundation Netherlands have been fighting tobacco from the start of the Dutch tobacco control advocacy movement. The Dutch Cancer Society holds the oldest track record in tobacco control advocacy and has the largest financial resources.

This chapter describes the emergence, transformation, and accomplishments of the Dutch tobacco control coalition ${ }^{1}$ and how it adapted to changes in the policy environment. It narrates how the three charities developed a tobacco control coalition with the Stichting Volksgezondheid en Roken (Dutch Smoking or Health Foundation) (STIVORO) as their main vehicle. STIVORO's accomplishments are described, with particular attention to its successes in the field of health education and smoking cessation and as the central tobacco control advocacy organisation in the Netherlands. It will also discuss the contribution to the tobacco control coalition of the medical community, the academic community, and governmental organisations. From the 1970s until the end of the 1990s the coalition fought a strong tobacco industry-dominated government, followed by a period in which tobacco control was supported by an activist tobacco control elite within the Ministry of Health. STIVORO and the

M. C. Willemsen, Tobacco Control Policy in the Netherlands, Palgrave Studies in Public Health Policy Research, https://doi.org/10.1007/978-3-319-72368-6_9 
charities collaborated with the ministry on its wish for stronger tobacco control. This changed around 2007 when new governments appointed health ministers who were more lenient towards the tobacco industry and several committed civil servants left the tobacco control team at the Ministry of Health, resulting in a temporary wakening of national tobacco control. The health charities later resumed their lead role, and recent years have seen a resurgence of a strong tobacco control coalition.

\section{Early Days of Dutch Tobacco Control}

The tobacco control movement in the Netherlands had a curious start in the 1960s, with two public figures who dominated the media: Robert Jasper Grootveld (Box 9.1) and Lenze Meinsma.

\section{Box 9.1 Robert Jasper Grootveld, "anti-smoke magician"}

One of the first activists was an initiator of the Provo youth counter movement in Amsterdam. Paradoxically, this well-known cult-figure, Robert Jasper Grootveld, started a crusade against the tobacco industry, but not against smoking, being a tobacco smoker and promoter of marihuana use. As a self-proclaimed anti-rook magiër (antismoke magician), he regarded the cigarette as the ultimate symbol of oppression by multinationals and their marketers, and provoked the tobacco industry and the Amsterdam police by writing the word "cancer" on tobacco billboard advertisements, for which he was repeatedly arrested-and once sentenced to jail (Duivenvoorden, 2009). Grootveld initiated famous weekly provocative "happenings" in Amsterdam, part of which was a purifying ritual involving the mass smoking of cigarettes and loud coughing. Other public protest performances were around a small bronze statue in the centre of Amsterdam dedicated to poor Amsterdam boys, called "Het Lieverdje"- a local tobacco manufacturer had donated the money for it. Grootveld used the statue as a symbol for the modern addicted consumer. These happenings, where participants were enticed to smoke collectively as a protest against smoking and the tobacco industry, were a commentary on the prevailing ethos, which was regarded as hypocritical. For decades, many who agitated against tobacco and the tobacco industry had been easily set aside as being anti-rook magiërs: fools not to be taken seriously. 
The Dutch Cancer Society started tobacco education activities in the 1960s, years before the government took responsibility. Lenze Meinsma, director of the Cancer Society from 1953 until 1978, was a physician with a passion for the fight against tobacco. Meinsma became a public figure in 1963 through frequent appearances on television and other media, where he relentlessly warned against the dangers of smoking. He conducted campaigns aimed at teachers and pupils (known as Actie Roken Jeugd), which ran from 1964 to 1975 . He also presented the first ideas about how tobacco should be tackled. He condemned the government for not doing enough, in the process turning into a well-known anti-tobacco activist.

In 1969 Meinsma published a small booklet, Smoking and Risks (Meinsma, 1969), which became known as Meinsma's "red book." In it, he presented a rough sketch of a comprehensive approach to the smoking problem. In addition to educating young people, he proposed that the government substantially increase tobacco taxation, put health warnings on cigarette packs, ban tobacco vending machines, restrict the sale of tobacco to specialty shops, initiate a ban on tobacco advertisements and promotion, ban smoking in government buildings and workplaces, ban smoking in restaurants and cinemas, ban smoking during sports events, and ban the sale of duty-free tobacco in airplanes and to military personnel. All in all, it was an ambitious package that proved to be far ahead of its time, despite the implicit endorsement of the state secretary from the Ministry of Health who in the preface to the book wrote that smoking was a "serious public health problem" responsible for about 30 daily deaths in the Netherlands.

Meinsma suffered the same fate as Robert Jasper Grootvelt. His activities received negative reactions from the public and experts, who felt his tone was too harsh and confrontational. He had become a lone wolf, howling in the dark. The charities learned from this that the fight against smoking could not be carried out by individuals, but required coordinated efforts from dedicated organisations and a cautious and diplomatic approach. In 1971 Meinsma negotiated with the Lung and Heart Foundations about collaboration with the Cancer Society-no easy task, as the three organisations were natural competitors in the charity market. Meinsma also approached medical specialist organisations. This resulted-in January 1971-in a letter from the scientific associations of four medical professional organisations appealing to the 
state secretary for health to take action and not leave tobacco solely to the charities. This led to a recommendation from the Health Council in 1975 to set up a national tobacco control organisation which became Stichting Volksgezondheid en Roken (Dutch Smoking or Health Foundation) (STIVORO), the national tobacco control organisation. The Health Council wrote, "Considering the number of yearly deaths caused by tobacco ... and the fact that smoking will continue to be a considerable problem for the coming 15 or 20 years, the creation of a dedicated institute to reduce smoking is justified" (Beernink \& Plokker, 1975).

\section{The Foundation of STIVORO}

In contrast to other countries, notably the United States and the United Kingdom, the health charities in the Netherlands wanted the government to take the lead in controlling tobacco. ${ }^{2}$ However, the Dutch Health Council realised the danger of being too dependent on the government and advised that a national institute for the reduction of smoking should be set up in such a way that it could develop its own policy and be reasonably independent of its financers (Beernink \& Plokker, 1975). It noted that the government had to weigh up multiple interests when it came to the smoking issue, including economic interests, so that it was undesirable that the government be solely responsible for the new institute, and advised that private organisations be the financial supporters and driving force. It also advised that the Dutch Cancer Society, Heart Foundation, and Lung Foundation take up this responsibility. These three organisations founded STIVORO on 24 December 1974, but were not willing to fully finance and remained dependent on governmental co-funding.

The foundation of STIVORO did not immediately result in a working organisation. During its first three years it was barely active, lacking the funds to appoint even a director, and the three founding charities could not agree on the best course of action to tackle the complex smoking problem. ${ }^{3}$ In the first three years, STIVORO's activities were limited to distributing Meinsma's educational materials to schools, for which it received a governmental subsidy. As the government was accountable for STIVORO's activities to parliament, the state secretary assured critical libertarian politicians that each activity proposed by STIVORO would be analysed against the criterion of not overly restricting individual liberties. ${ }^{4}$ 
Three years after its foundation, STIVORO finally secured enough money to appoint a director and a small staff. It started to build up a network of academics who could advise on the scientific development of campaigns and overall strategy. A Wetenschappelijke Adviesraad (Scientific Advisory Council) was set up and in February 1978 Albert Pontfoort, the first director, presented STIVORO's policy programme to the press (STIVORO, 1978). The approach was to stimulate smokers to change their behaviour through campaigns that could be tailored to smokers' psychological determinants, applying methods and insights from psychology and the new fields of communication sciences and health education. Until then, STIVORO's activities had been restricted to informing the public about the health risks of smoking. The new approach was a direct translation of State Secretary Hendriks' Tobacco Memorandum (see Chap. 2). A comprehensive, long-term approach was proposed that included continued education of youth, protection of non-smokers against environmental tobacco smoke, and development of behavioural support for smokers who wanted to quit. Exposing tobacco industry strategies and lobbying for regulatory measures from the government were not explicitly mentioned.

At first the Ministry of Health did not want to structurally finance the new organisation, and limited subsidies to specific activities and ad hoc campaigns under more or less formal grant proposal conditions. In this way the government could control educational measures, which it regarded as its main responsibility in the fight against tobacco, without being responsible for a new semi-governmental organisation. This must be understood against the backdrop of a process in which the ministry explored ways to organise health education in the Netherlands. Health education was a new profession, and while the government wanted a national institute for the coordination of national and local health education activities, it had not yet decided if tobacco was going to be a part of this. Pending this decision, it was not prepared to structurally support STIVORO. It took three years before a compromise was reached, in which the three charities equally financed half of the bureau and the other $50 \%$ was financed by the government, but still in the form of project finance. The total budget for the organisation was one million guilders. ${ }^{5}$ This understanding lasted until 1991, when the government began to finance STIVORO on a structural basis, not at $50 \%$, but by the same amount that the three "mothers" each paid: 350,000 guilders. From 1991 onwards STIVORO was a semi-governmental organisation with one quarter of its core finance flowing from the Ministry of Health. 
For many years the charities were not prepared to publicly operate as activist organisations. They were concerned that a too radical or confrontational approach would backfire, jeopardising the goodwill of donors (De Jong, 1989), remembering that Meinsma's rhetorical style had prompted negative reactions. Public opinion was antagonistic to a paternalistic approach, and the three organisations depended on private donations. By supporting STIVORO they could fight tobacco without standing directly in the spotlight. ${ }^{6}$ The downside was that STIVORO had to walk a tightrope, balancing interests from three charities and the government.

Over the years STIVORO became more and more dependent on governmental subsidies. The Ministry of Health was on the management board, although it had no voting power. Internationally, the arrangement was unique, and typically Dutch: compromises between government and civil society were woven into the fabric of the organisation. Because of the collective financing arrangement, the three "mothers" and one "stepmother" (the state) held each other hostage, making it very difficult for any partner to withdraw its support. If one organisation wanted to pay less (or more), it had to convince the others to do the same, and if one wanted to withdraw altogether, the remaining three were unlikely to agree since they would then have to cover the costs of the dropout. However, this assured STIVORO of secure core funding for several decades, which can be considered as one reason for its success.

\section{The Tobacco Control Coalition Expands}

At the end of the 1970s the core of the Dutch tobacco control advocacy coalition consisted of the three charities, united in STIVORO, and their counterparts at the Ministry of Health. From the start it collaborated with Clean Air Netherlands (CAN; discussed in the next paragraph), which was founded in the same year as STIVORO. Over the years STIVORO expanded its network, mainly in the medical sector: in the mid-1990s through the Dutch Medical Alliance Against Smoking, and from the beginning of the 2000s through the Partnership Stop Smoking.

\section{Clean Air Netherlands}

The Club for Active Non-smokers, later dubbed Clean Air Netherlands $(\mathrm{CAN})$, is a grass roots interest group founded in 1974 to protect the 
rights of non-smokers. From the beginning it received material and a small financial contribution from STIVORO, and in the first years the two organisations shared a post office box. It survived on donations and gifts from members and supporters. In 1979 analysts from the tobacco industry identified CAN and STIVORO as the two main Dutch anti-tobacco organisations (Unknown (Philip Morris), 1979). In their eyes CAN was immature, and "due to their inability and their rather passive attitude, they have played a non-effectual role." STIVORO was the "most active and serious anti-smoking group at this time, [but] as the personal freedom concept is widely accepted and supported in Holland, the anti-smoking cause is not exceptionally strong."

Despite its dismissal by the industry, CAN played a significant role in the fight for smoking bans. STIVORO collaborated with CAN if it needed an activist approach to put issues on the agenda, which it could not do under its own name. CAN exists to this day and has at times been an effective grass roots advocacy organisation, operating fairly independently of the broader STIVORO-led tobacco control coalition. It does not shy away from taking the government or companies to court. In 1995 CAN campaigned against national airlines (Transavia, Martinair, KLM) to ban smoking during flights. After 2004 it campaigned for a smoke-free hospitality sector. A major accomplishment was that they were the first organisation in the Netherlands to make use of a new right to citizens' initiative: anyone who can present 40,000 supporting signatures can put an issue on the official agenda of parliament. CAN handed in about 62,000 signatures to the president of parliament in May 2006, in an attempt to implement a smoking ban in bars and restaurants on the agenda. Parliament, however, did not discuss the topic because it had already debated several times on the smoke-free issue, and the citizens' initiative is not valid if the topic has been debated before. In 2007, in a collaborative action with STIVORO, CAN presented 60,000 letters from citizens who asked for a smoke-free hospitality sector, and presented these to the negotiators during the formation of the Balkenende IV cabinet, which contributed to the smokefree hospitality sector becoming part of the coalition agreement of the cabinet. CAN's biggest success was the court case against the state over Minister Schippers' one-sided decision to exclude small bars from the smoking ban. The judge overruled the minister, who was defeated in the high court in 2013. 


\section{The Medical Sector}

A remarkably weak link in the Dutch tobacco control health coalition was the passive stance of the medical community. After the initiative from medical specialist organisations in the beginning of the 1970s that resulted in the foundation of STIVORO, the medical establishment was happy to leave tobacco control advocacy to STIVORO. This may be because in the 1970s and 1980s smoking among physicians was very common. About half of all general practitioners smoked, and smoking rates were higher than in the general male population and much higher than what was normal in the higher social classes (Adriaanse, Van Reek, \& Metsemakers, 1986; Vandenbroucke, Kok, Matroos, \& Dekker, 1981). While in many countries smoking rates decreased earlier in the medical professions than in the general population, this was not the case in the Netherlands. In a review of data from 31 countries, only in France, Portugal, and the Netherlands did more physicians smoke than in the general population (Adriaanse, Van Reek, \& Van Zutphen, 1986).

The passive stance of doctors may be further attributed to active lobbying by the tobacco industry. In 1979 the industry's Tobacco Education Bureau (BVT) began to distribute Rookspectrum, a periodical with "scientific information" on the smoking and health issue, to all Dutch family practitioners. Rookspectrum presented a selection of scientific news about smoking, downplaying the health risks of smoking and passive smoking. Its aim was "to defend issues concerning passive smoking" (RJ Reynolds, 1979). This free "service" to doctors continued for at least four years. In 1985 the industry boasted that, based on a survey they carried out among more than 1200 doctors, $70 \%$ said they were readers of the journal and $54 \%$ believed that Rookspectrum provided a meaningful contribution to the smoking and health discussion (SNK \& SSI, 1985).

Surveys in the 1980s showed that Dutch general practitioners did not regard their exemplary role as particularly important (Adriaanse, Van Reek, \& Metsemakers, 1986; E. Dekker, 1981). One in four family physicians smoked in the presence of patients (Dekker, 1981). Dutch physicians considered smoking a private lifestyle choice for which they were not responsible, were stoic about the need to fight the tobacco epidemic, and ignored the important role they could play (Knol, 1997).

The main medical organisation in the Netherlands is the Koninklijke Nederlandsche Maatschappij tot bevordering der Geneeskunst (Royal Dutch Medical Association) (KNMG), established in 1849. The KNMG repre- 
sents all medical professions. In an editorial, the scientific journal of the KNMG called on the medical profession to become more actively involved in the political lobby (Van Es, 1987), but this did not result in a more activist role. In $2005 \mathrm{KNMG}$ was asked to give its views on the government's tobacco control agenda. It briefly mentioned the need for a smoking ban in the hospitality sector, but emphasised the importance of smoking cessation, which they regarded as the main contribution the medical community could make (Rijksen, 2005); it did not mention tobacco control in its 2007 prevention policy document (KNMG, 2007). For decades the KNMG has not taken a particular interest in tobacco control advocacy and confined itself to being a member of the Partnership Stop Smoking. This situation lasted until 2016 when the KNMG felt certain enough to step forward with a distinctive and explicitly formulated tobacco control agenda, urging the government to do a better job of implementing WHO's Framework Convention on Tobacco Control (FCTC) measures (KNMG, 2016). The same lack of activism by the Dutch medical community was noticeable in the unremarkable role that the powerful Landelijke Huisartsen Vereniging (Dutch General Practitioners Association) (LHV)—established in 1946 to defend the interests of general practitioners-played in Dutch tobacco control.

In 1993, medical specialists founded the Medische Alliantie tegen het Roken (Medical Alliance Against Smoking), a Dutch branch of the European Medical Association Smoking or Health. The secretariat was provided by STIVORO. For many years the Medical Alliance was the only active medical tobacco control advocacy organisation, but it had no real political power, being a voluntary organisation with no resources, and dependent on the goodwill of a small number of engaged doctors and retired medical professors. Despite this, on various occasions the organisation was able to highlight failings in the self-regulation of tobacco advertising (Knol, 1995, 1996a, 1996b), sometimes together with the KNMG (Lanphen \& Van Berkestijn, 1995). The most notable activity was a petition to the parliament, signed by 185 medical professors, asking for an advertising ban (Hilvering, Knol, \& Wagener, 1995). This supported Health Minister Borst, who endeavoured to get a ban on tobacco advertising in the Tobacco Act. The Medical Alliance remained active until 2008 when it was dissolved, partly due to lack of interest from the medical community.

The Dutch doctors' passivity is in contrast with the important role that the medical community played in the United Kingdom. Early on, the UK 
Royal College of Physicians published influential reports on the health risks of smoking and advocated for tobacco control measures, such as in their Smoking and Health report (Royal College of Physicians, 1962). It founded Action on Smoking and Health (ASH UK) in 1971 to lobby for better tobacco control by the government. Another strong medical force was the British Medical Association (BMA). In 1984, the BMA started an unprecedented attack against the tobacco industry in an attempt to eradicate tobacco advertising and promotion (BMA, 1986). Voluntary agreements to restrict advertising, comparable with those in place in the Netherlands, were not working, and the BMA realised that something had to be done to break the deadlock. The campaign carried the weight of the BMA's prestige and infrastructure (representing the majority of practising doctors in the United Kingdom), and one of the most highly organised professional bodies in the country, directly into a fight with the industry. It was a tremendous help for ASH UK, which, like STIVORO at the time, was a small organisation with only three full-time officials and five support staff. David Simpson, ASH's director, more than welcomed the help of the BMA, which had a reputation as one of the country's most powerful lobbying organisations: "It was like the Americans entering the Second World War" (BMA, 1986, p. 7). The campaign lasted several years, permeated the media with a general anti-tobacco climate, and put pressure on ministers to take the smoking problem more seriously. No such help from the medical community materialised in the Netherlands.

\section{A Public-Private Partnership to Support Smoking Cessation}

In 2000 STIVORO formed a coalition of organisations with expertise and interest in the treatment of smokers, under the name Partnership Stop met Roken (Partnership Stop Smoking). This was at the request of Health Minister Borst, who wanted to improve the quality of the treatment of tobacco addiction. The new coalition was launched in January 2002 as a public-private partnership and received financing from the Ministry of Health (€550.000 for the first two years). ${ }^{7}$ The Partnership Stop Smoking included the KNMG, the Dutch Medical Alliance against Smoking, the Association of Doctors for Lung Disease and Tuberculosis, the Dutch Cardiology Association, the Dutch Institute for Psychologists, various addiction treatment organisations, health charities, scientific organisations, and several pharmaceutical companies. STIVORO initiated and 
coordinated the Partnership. Its main activity was to develop the first clinical guidelines for the treatment of tobacco dependence, following examples from the United States and the United Kingdom. It was hoped that such guidelines would encourage Dutch health-care professionals to motivate patients to quit smoking and also to engage more doctors in tobacco control activism. The Partnership identified its mission as placing the gravity of tobacco addiction and the urgent need to tackle this problem higher on the political agenda. Advocacy goals were a smoke-free workplace and hospitality sector, and reimbursement for smoking cessation, including for pharmaceutical treatment. The Partnership was the Dutch representative in the European Network for Smoking Prevention (ENSP). With support from the Partnership, the lobbying strength of the three charities and STIVORO improved considerably, because they were able to mobilise a much broader group of organisations.

In the first year of the Partnership, when STIVORO looked for overseas examples of how a network of tobacco control professionals could be organised, it identified Canada as a model. In November 2000 the Canadian activist Heidi Rathjen gave a workshop in the Netherlands to inspire the new Dutch coalition. Rathjen had founded the Quebec Coalition for Tobacco Control in 1996, a coalition of about 700 organisations that successfully pushed the government to make haste with drafting a Tobacco Act (Rathjen, 1999). In 2004 STIVORO, through the Partnership, called on the government to ratify the FCTC (Partnership Stop met Roken, 2004), which it did in 2005. In 2011 the Partnership campaigned for continuation of the national reimbursement for smoking cessation support, presenting a petition to politicians in the spring of 2011 and organising a press lunch with politicians at the end of that year. After this was accomplished, the Partnership Stop Smoking became an independent foundation which focused on further improving the quality of smoking cessation treatment in the Netherlands (see also Box 10.1 in the next chapter). The Partnership Stop Smoking was the first European organisation to develop clinical guidelines for the treatment of tobacco addiction, after the United Kingdom.

\section{The Scientific Community}

How much support did the Dutch tobacco control lobby get from the scientific community? Academics can have much influence on policymak- 
ing when they become media personalities, by appearing on radio and television, writing opinion pieces and popular books, and using the authority of scientific papers to tell their story (Chapman, 2017). Dutch academics did sporadically speak out for more effective tobacco control in the media, sometimes attracting attention from politicians. For example, the fact that the implementation of the Tobacco Act in 1990 was not followed by a noticeable impact on smoking rates (Dresscher, Elzinga \& Koldenhof, 1991) led to critical remarks from prominent Dutch scientists about the national tobacco control policy (Barneveld, Dalesio, \& van Leeuwen, 1992; Roscam Abbing, 1992). Johan Mackenbach, professor of public health at Erasmus University, regularly criticised the government for insufficient disease prevention and its weak tobacco control policy (Mackenbach, 2006, 2009, 2016; Mackenbach, Klazinga, \& Van der wal, 2004). My own inaugural lecture was a catalyst for heighted attention to failed Dutch tobacco control policy (Willemsen, 2011, 2012; Willemsen, De Vries, \& Van Schayck, 2009).

Over the years, STIVORO developed collaborations with various universities, predominantly concerned with building an evidence base for education, campaigns, and smoking cessation interventions-tobacco control advocacy was seldom the topic. The Netherlands has fewer research activists in the field of tobacco control than in some Anglo-Saxon countries. For example, the American tobacco control movement included notorious academic tobacco control advocates, committed to getting tobacco multinationals on their knees (Derthick, 2005). Tobacco control advocacy, at least when it is done through extensive and public media advocacy, is regarded by many in the Dutch academic community as difficult to reconcile with the scientific enterprise. When academics become too involved in activism, they may be perceived as pushy and stepping over the fine line of relationships in the Dutch corporatist system, where one needs to be part of the system to have influence.

\section{Support from Governmental Agencies}

The role of state agencies as an integral part of the tobacco control movement has been limited in the Netherlands. Dutch national governmental agencies such as the Rijksinstituut voor Volksgezondheid en Milieu (National Institute for Public Health and the Environment) (RIVM) and Nederlandse Voedsel en Waren Autoriteit (Netherlands Food and Consumer Product 
Safety Authority) (NVWA) were (and are) not tasked to actively support and promote tobacco control activism at the state or local level. This contrasts with the United States, where federal governmental agencies such as the office of the Surgeon General, the National Cancer Institute, and the Center for Disease Control and Prevention played crucial roles. These organisations spent millions of dollars to fund advocacy efforts, disseminated scientific research findings in support of the health lobby, and provided training and technical assistance to advocates at local, state, and federal levels (Wolfson, 2001). For example, the National Cancer Institute, with support from the American Cancer Society, initiated and funded the multi-state project American Stop Smoking Intervention Study for Cancer Prevention (ASSIST), providing a massive injection of federal resources into state and local tobacco control advocacy (Wolfson, 2001).

\section{The Golden Years of Dutch Tobacco Control}

In 1987, parliament insisted that educational efforts to discourage smoking be intensified. ${ }^{8}$ The goal of $20 \%$ smokers in 2000 could not be reached without more money for education, as tobacco promotion by the industry was still completely unregulated. The government agreed and brought together a group of experts to develop a multi-annual action plan. The proposal consisted of a comprehensive approach to youth education, smoking cessation, special attention to high-risk groups and protection of non-smokers, with yearly smoking cessation media campaigns as a core element, all to be coordinated and organised by STIVORO. This signified a change in STIVORO's focus, as it now became responsible for coordination and execution of national tobacco control action plans for the government. Its main activity was to organise yearly nation-wide smoking cessation campaigns in collaboration with national and local health organisations.

STIVORO's campaigns were highly successful and contributed to significant reductions in smoking in the Netherlands (see Box 9.2). Between 1986 and 2011, STIVORO organised 16 campaigns around smoking cessation. While the campaigns in the 1980s and the beginning of the 1990s still had an educational character (e.g., the 1986 campaign informed smokers about how misleading light cigarettes were), the campaigns after 1996 also went on to inform smokers about cessation support. 


\section{Box 9.2 STIVORO's great "smoke-outs"}

Betweewn 1990 and 2008, STIVORO organised four large-scale media campaigns that involved entertainment-education strategies (such as TV shows) and stimulated between $20 \%$ and $30 \%$ of all smokers to make quit attempts (Willemsen, van Kann, \& Jansen, 2012). The campaigns were accompanied by the introduction of cessation methods that were innovative for their time, such as a television cessation clinic (Teleac) in 1990-1991, a national telephone quit line and entertainment-education (TV entertainment shows) in 1999-2000, and a self-help cessation kit in 2003-2004.

The 1990-1991 campaign "Quit smoking together" featured a series of informative and entertaining television programmes showing celebrities trying to quit smoking, a TV cessation clinic, 73 cessation clinics conducted at the local level, a national quit line staffed by trained counsellors, and a comprehensive publicity campaign (Mudde \& De Vries, 1999). The campaign contributed to a reduction in the proportion of smokers from 35\% in 1990 to $34 \%$ in 1991. This seems modest at first glance, but is impressive when one considers the fact that between 1990 and 1991 the tobacco industry increased its expenditure on tobacco promotion and advertisements by $72 \%$ (from $\$ 66$ to $\$ 113$ million) (Mudde \& De Vries, 1999).

The "I Can Do That Too" "millennium" campaign ran in 1999-2000 and was made possible through an extra subsidy by the Dutch Cancer Society, celebrating its 50th anniversary. During the period of the campaign more than 600,000 smokers attempted to quit: four times more than usual (Op de Weegh \& Willemsen, 2003; Westerik \& Van der Rijt, 2001). The campaign contributed to a reduction in national smoking prevalence from $34 \%$ to $33 \%$.

The "Netherlands Start Quitting" campaign in 2003-2004 was financed by the Ministry of Health and aimed to accelerate the natural quitting that was expected to occur with the implementation of the workplace smoking ban. It was associated with a reduction in smoking prevalence from $27 \%$ to $25 \%$, with more than a million quit attempts at or around New Year's Eve (Van den Putte, Yzer, Ten Berg, \& Steeveld, 2005). In the same period, STIVORO ran campaigns to inform employees about the workplace ban and to motivate smoking parents to quit ("Kinderen Kopiëren"). 
The last large campaign was the "In every smoker there is a quitter" campaign in 2008, financed by the three charities as part of the Nationaal Programma Tabaksontmoediging (National Programme of Tobacco Control) (NPT): the idea was that the implementation of the smoking ban in the hospitality sector in July 2008 would result in many smokers wanting to quit. The campaign ran between April 2008 and January 2009 and stimulated smokers to take the opportunity to quit. It is estimated to have contributed to between 1.1 and 1.4 million quit attempts, twice the number that would have quit normally during the same period (Nagelhout, Willemsen, van den Putte, Crone, \& de Vries, 2009; STIVORO, 2009). Smoking prevalence dropped by $0.8 \%$ (STIVORO, 2009).

At the end of the 1980s, STIVORO began to coordinate smoking cessation initiatives at the local level through collaboration with municipal public health services and regional cancer centres. It set up a national council with representatives from municipal health services, home nursing organisations, and experts from several universities to coordinate and prepare annual cessation campaigns. In addition, it organised national meetings where scientists exchanged information on research findings. Over a period of three decades, STIVORO steadily extended and improved its repertoire of smoking cessation support. It became an internationally acknowledged example for other countries of how evidence-based cessation support can be integrated with yearly mass media cessation campaigns, and how to offer cessation support through the internet. An important feature of the Dutch system was that government funding allowed STIVORO to offer cessation support free of charge. Through close collaboration with the University of Maastricht, STIVORO became an international pioneer in evidence-based smoking cessation methods. These included self-help manuals; computer-tailored cessation materials; cessation protocols for use by general practitioners; specialised protocols for use with cardiac patients, lung patients, and pregnant women; and special programmes to motivate and support smoking employees to quit smoking at the workplace. Sometime around 2000 STIVORO set up a well-staffed smoking cessation telephone quit line. It was one of the leading partners of the European Network for Quitlines and, alongside 
Sweden, the only quitline organisation that conducted scientific research to improve quitline counselling.

When the economy improved, the money that STIVORO could spend on campaigns was allowed to grow. It increased almost exponentially between 1993 and 2004, while the structural budget for the organisation remained fairly constant (see Fig. 9.1). The campaign budget reached a peak in 2003 with a total of $€ 16$ million. This large sum followed the resolution from Senator Werner that was key to getting approval for Minister Borst's Tobacco Act in the senate (discussed in Chap. 2). In 1996 STIVORO was already the best staffed and funded tobacco control organisation in Europe (Boucher, 2000), but the period from 1999 until around 2004 is considered by some to be the golden years of STIVORO, and Dutch tobacco control in general, as this period coincided with the adoption and implementation of the revised Tobacco Act. ${ }^{9}$ STIVORO's size grew from around 9 employees in 1989, to 18 in 2000, and 46 in 2004. ${ }^{10}$ The large number of employees from 2000 onwards reflected the many smoking cessation counsellors who worked in STIVORO's advice centre and smoking cessation quitline.

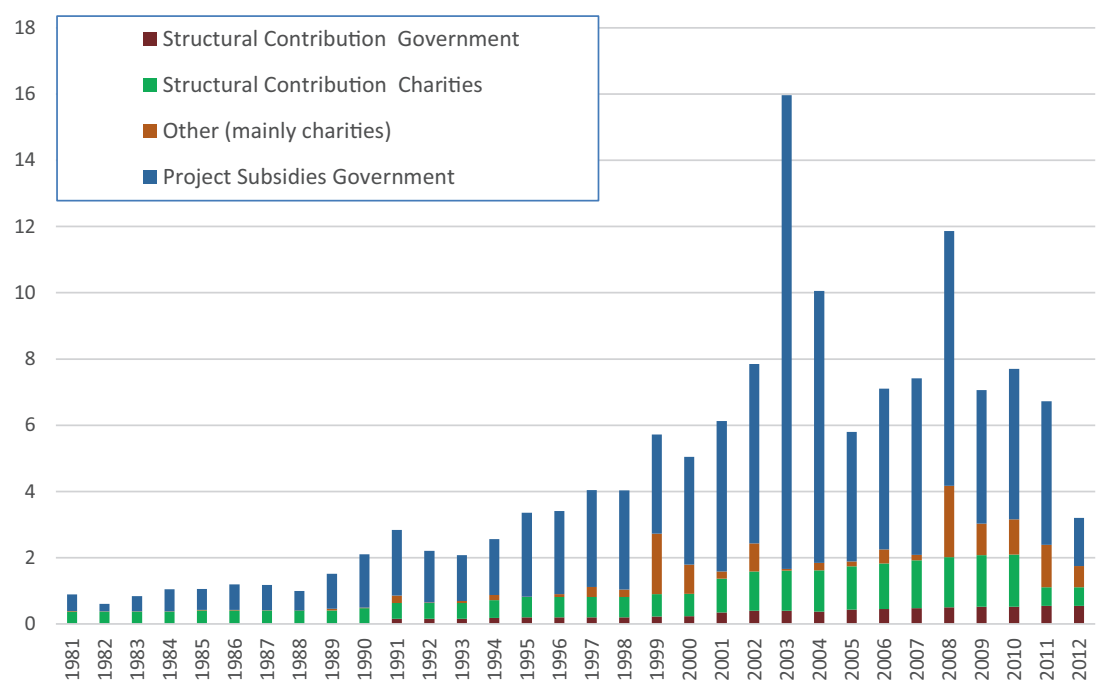

Fig. 9.1 STIVORO's budget ( $\times$ million Euro). Source: STIVORO's annual reports 1981-2012 
In the years between 2000 and 2008, the tobacco control team at the health ministry, which collaborated closely with STIVORO, was also rather large, and there was a strong team spirit, according to all interviewees. The team was supported by specialists from the ministry for such things as juridical and financial matters, and occasionally increased to a team of six to ten people. ${ }^{11}$ In later years the team was downsized. ${ }^{12}$

\section{Cracks in the National Tobacco Control Coalition}

In the 40 years of its existence, STIVORO struggled with its mandate in tobacco control, trying to strike a balance between the sometimes competing interests and expectations of its three "mothers" and the government. The government and parliament regarded health education as STIVORO's sole task, but civil servants from the ministry and the charities expected STIVORO to lobby in parliament for better tobacco control policy, despite the fact that it had no professional lobbyists. A civil servant explained: "The lobby that the health organisations put up in the direction of the parliament was rather amateurish in our eyes. That was no reproach to anyone. We found that quite normal, since the business community was so much better in lobbying." 13 When judging the limited lobbying capacity of STIVORO, another civil servants observed: "STIVORO's people were of course constantly busy with education, with producing materials etc. They did not have the time, day in, day out, to gain skills in lobbying." 14 The more STIVORO became dependent on large subsidies from the government, the more difficult it was to criticise the government. Similar worries were felt in other countries. For example, ASH UK (STIVORO's counterpart in the United Kingdom) depended in the 1980s for $90 \%$ of its annual grants on the Department of Health. ASH "felt itself to some extent constrained in what it could say or do" (BMA, 1986).

Political parties opposing tobacco control criticised STIVORO's lobbying activities. For example, during a debate with parliament about the Ministry of Health's budget, the liberal-conservative representative of the Volkspartij voor Vrijheid en Democratie (People's Party for Freedom and Democracy) (VVD) criticised an advertisement that STIVORO had distributed protesting against tobacco advertising. The VVD argued that STIVORO must refrain from lobbying on the ground that taxpayers' money was being used for lobbying instead of health education. However, State Secretary for Health Hans Simons supported STIVORO as a matter of principle: "I think that subsidised organisations must have a large degree 
of liberty. ... I believe that such organisations must be able to critically express themselves about governmental policy. I firmly support that." ${ }^{15}$ At the end of the 2000s, when such support from ministers was missing, criticism about the fact that STIVORO lobbied while it received government subsidies continued to be voiced by industry-friendly parliamentarians and eventually contributed to the government's withdrawal from the organisation.

\section{The Three Health Charities Stepping Out of the Shadows}

The adoption of the Tobacco Act in 1988, which led to more societal support for tobacco control, signified a first breach with the charities' taboo on tobacco control activism (De Jong, 1989). However, the largest change was with the implementation of the amended Tobacco Act in 2002. The successful smoking ban and advertising restrictions profoundly changed social norms about smoking in society. The charities began to feel more confident and stepped out of the shadows, hoping that their contribution to tobacco control would become more visible to the general public. Between 2001 and 2003, the Cancer Society started several high-profile smoking cessation campaigns targeted at pregnant women, and experimented with popular national "Quit \& Win contests," where smokers who quit smoking would be eligible for a prize.

The year 2005 signified a major change within the health coalition. The three charities were no longer willing to give STIVORO carte blanche to play an advocacy role in tandem with civil servants from the Ministry of Health. The governing board of STIVORO (which consisted of representatives from the three charities, including their directors and representatives from the Ministry of Health) stepped down and was replaced by a board of trustees. The three charities could each nominate one candidate to the board. Former Health Minister Els Borst was one of the seven members; the ministry itself had no seats on the board. This allowed the charities to pursue their own agenda. In June of that year the directors of the three charities and Hoogervorst put their signatures to an intention document to collaborate closely in the National Programme Tobacco control (NPT 2006-2010). STIVORO's role was restricted to execution of the NPT, as "knowledge and expert centre, service and support provider and educator in the field of tobacco control" (Hoogervorst, Zoun, De Blij, \& Hanselaar, 2005). In addition, the charities began to make STIVORO more accountable for the money they spent on tobacco control. 


\section{In Search of a New Strategy}

During the four years that the NPT lasted, it became increasingly clear that the NPT coalition did not function well and that the goal of $20 \%$ smokers by 2010 would not be met (a more detailed discussed of the NPT programme can be found in Chap. 2). The three charities lacked a common vision on how tobacco should be tackled and the Ministry of Health lacked political support to pursue new tobacco control initiatives. In January 2007 the three charities desperately called on the government to make more money available for smoking cessation campaigns (STIVORO, 2007), but this was to no avail. Since Minister Klink was unwilling to deliver regulative measures, both STIVORO and the charities began to look out for other ways to advance tobacco control, trying to escape the deadlock. They explored new ways to denormalise the tobacco industry and tobacco use, to create a more coherent national policy, and to build societal support, inspired by best practices from California, Australia, Canada, and Finland (STIVORO, 2010a, 2010b). STIVORO presented its new vision in June 2010 at a symposium where it commemorated its 35-year anniversary. Reports presented to the press emphasised that Dutch smokers were still relatively unconcerned about smoking (ITC Project, 2010) and that more must be done, which led to headlines in the media such as "Are the Dutch too soft on smokers?."

In 2010 the NPT's goal of $20 \%$ smokers was not reached. With the failure of the NPT programme, the three charities decided to start a new alliance, and began preparatory talks. In December 2010 they announced that they wanted to withdraw their finances from STIVORO. On 6 January 2011 a small group of individuals from the three charities, STIVORO, CAN, Trimbos Institute, the Association of Municipal Health Services, and the Stichting Rookpreventie Jengd (Youth Smoking Prevention Foundation) (SRJ) came together to discuss the next steps in Dutch tobacco control. There was an agreement that this time a proper coalition should be built, with the three charities taking the lead but supported by a wide range of organisations, and coordinated by a professional bureau. There should be ample room for grass roots initiatives, and the core activities would be empowerment, lobbying, and alliance building. The other existing alliance, the Partnership Stop Smoking, became an independent foundation in that same year and was destined to become part of the new alliance because of its important role in the quality assurance of smoking cessation treatments. STIVORO would be given the role of expert centre 
on tobacco control, but not lobbying, advocacy, and communication, which would be handled by the three charities.

In March 2011 STIVORO and the Dutch Cancer Society hosted the European Conference on Tobacco Control in Amsterdam. At the conference, the results of the Tobacco Control scale were presented. The Netherlands ranked 13 of 28 , one place down from the previous measurement (Joossens \& Raw, 2011). This supported the idea that the Dutch government could and should do more in terms of its FCTC requirements. In the aftermath of the European Conference, STIVORO organised a national "inspirational conference" to explore how the Dutch health network could be transformed into a more effective tobacco control alliance (Van Emst \& Willemsen, 2011). Experts from Sweden and Ireland presented successful tobacco control alliances from their countries.

\section{The End of STIVORO}

On 25 May 2011, STIVORO received notification from the Ministry of Health that its structural subsidy would be cut by $25 \%$ in 2013 and by $50 \%$ in 2014. A month later another letter confirmed that all subsidies would end by 2013 and tobacco control would be integrated into the alcohol and drug prevention activities of the Trimbos Institute. This decision took STIVORO out of the equation, and paved the way for a new coalition. In the summer of 2011, after a study tour to the United Kingdom to find inspiration from how the British organised tobacco control advocacy, the charities understood that they had to broaden the fight for tobacco control by including societal organisations in a broad coalition. The alliance was to become a coalition of autonomous organisations that collaborated for a common goal with preservation of each one's identity and responsibilities. It was recognised that success was dependent on mutual trust and respect for each other's interests, a set of common goals that bound and unified, and formal and informal rules for mutual cooperation, including how to embed the alliance into the internal workings of the three charities. A professional management consultant was hired to lay the foundation.

At the end of 2013 STIVORO was officially disbanded. In January 2014 the Alliantie Nederland Rookvrij (Dutch Alliance for a Smokefree Society) (ANR) began to coordinate the tobacco control advocacy activities of the three charities, while STIVORO's budget and tasks regarding smoking cessation and educational were taken over by the Trimbos Institute. 


\section{The Youth Smoking Prevention Foundation}

The failure of the NPT programme and the chaos in which the tobacco control coalition with STIVORO as centrepiece had found itself opened the way for other initiatives. In 2009 Wanda de Kanter and Pauline Dekker, two chest physicians, founded the SRJ, motivated by the fact that they were treating lung patients every day who were seriously sick or dying from smoking, while the cause (the tobacco industry) went unchallenged and the government failed to take appropriate measures to discourage new smokers. The two lung specialists built a coalition of organisations and individuals that became an inevitable new activist lobbying force in the Netherlands, operating fairly independently of the main tobacco control coalition. The group included journalists, lawyers, scientists, and influential people from the medical and political elite (Youth Smoking Prevention Foundation, 2014). De Kanter and Dekker became increasingly influential through media advocacy activities, including appearances in high-profile television shows and a strong presence in social media. In January 2011 they presented a manifesto, "Keep our youth smoke-free," co-signed by hundreds of physicians and sympathisers, to Health Minister Schippers, in which they called on her "to do all in her power to make tobacco addiction a thing of the past for future generations" (Youth Smoking Prevention Foundation, 2014). When Schippers rejected their proposals, they decided it was time for a more confrontational approach. In 2013 they began to explicitly name and shame tobacco industry representatives and people associated with the industry network through the website www. tabaknee.nl, and set out a programme for revealing tobacco industry tactics; for example, through investigative journalist pieces in Dutch magazines. Some of the revelations led to questions in parliament, putting more pressure on Schippers, who eventually in the second cabinet Rutte handed over the "hot" tobacco control dossier to State Secretary Martin van Rijn. See also Chap. 6, where the SRJ's successful attempt to take the State to court for violating Article 5.3 FCTC was described. In 2016 the Youth Smoking Prevention Foundation filed charges on behalf of lung cancer patient Anne Marie van Veen and Chronic Obstructive Pulmonary Disease (COPD) patient Lia Breed, against four tobacco manufacturers, accusing them of attempted murder and manslaughter, the first criminal case against the tobacco industry anywhere in the world (SRJ, 2017). 


\section{Accomplishments of the Tobacco Control Advocacy CoAlition}

The preceding account might suggest that the tobacco control coalition led by STIVORO was not particularly effective in advocacy and lobbying since it was financially tied to the government and was preoccupied with educational and smoking cessation activities. Although its main contribution to reducing smoking rates was undoubtedly through mass media campaigns and the implementation and coordination of education and smoking cessation interventions, during its almost 40 year of existence its advocacy activities, which sometimes brought it in direct collision course with the tobacco industry, did have impact on the government's tobacco control policy as well.

Lobby and press contacts were the responsibility of STIVORO's directors, who had to combine these responsibilities with management tasks, so success with lobbying very much depended on the capacity and personal affinity of each director. STIVORO has had six directors since it was founded in 1974. The charities allowed them to decide lobbying strategy. Each director put a unique mark on the organisation and on the way the health network functioned. In the remainder of this section, I describe STIVORO's lobbying accomplishments, organised according to the leadership of the last four directors who left distinct marks on Dutch tobacco control.

\section{Roch de Jong (1981-1995)}

While the cabinet persisted in its unwillingness to regulate tobacco advertisements during the 1980s and 1990s, STIVORO just as persistently tried to keep the need for a tobacco advertising and promotion ban on the political agenda. STIVORO was a critical and persevering watchdog of the various centre-right-wing cabinets that did not invest in tobacco control. The driving force was Roch de Jong, director from 1981 until 1995.

De Jong had been a colonel in the TRIS, the former Dutch armed forces in Surinam. He was a strong personality, not afraid to confront the government or the industry. He transformed STIVORO from a passive to an active lobbying organisation. Jean Nelissen, a former marketer with the multinational Unilever, was hired for public relations. "With Nelissen, we took in a streetfighter," recalled Roch de Jong (Bouma, 2001). In 1983 Nelissen bought a pirated tape of the documentary Death in the West, an 
anti-Marlboro documentary that for many years was kept out of public view by lawyers from Philip Morris. Nelissen showed the film to State Secretary for Health Joop van der Reijden, who was impressed and said in an interview that the film should be broadcast in schools, and that he intended to take further measures against tobacco advertising (Bouma, 2000).

In the 1980s the government had no tobacco control policy to speak of. According to one former official,

A real policy? I wouldn't even know. There might have been a letter to parliament on tobacco, but it rained incidents. The driving force was the dynamic coming from STIVORO's Jean Nelissen. Roch de Jong was also on my back all the time. He was often at the Department. But the Ministry of Health itself was non-existent on the tobacco dossier. ${ }^{16}$

Illustrative of STIVORO's approach in these years is a letter from De Jong in 1984 to parliament and cabinet, in which he criticised the government's long-awaited proposals for a Tobacco Act (De Jong, 1984; De Jong \& Nelissen, 1984). He meticulously criticised the fact that the proposal did not include elements that would harm the industry. It was instead in line with the prevailing spirit of reducing the state deficit and putting sole priority on stimulating the economy. He demanded that the government abandon its passive stance, arguing that the current proposals would in no way contribute to effective tobacco control. Instead he listed the things that should be done: reducing the sale of tobacco to specialty shops, regulating tobacco advertising, substantially increasing the government's subsidy to STIVORO (he suggested reserving $0.1 \%$ of the tobacco tax revenues), increasing tobacco taxation, and involving STIVORO in all future preparation for a new tobacco policy.

Ben Baan, STIVORO's scientific officer, published a paper in the Dutch Medical Journal, criticising the weak draft to the Tobacco Act, in the same spirit as his director. Baan complained that STIVORO's educational efforts could not compete with tobacco advertising because the tobacco companies had enormous budgets while STIVORO was insufficiently funded by the government (Baan, 1986). He was transparent and open about STIVORO's new strategy: the former neutral focus on merely education was replaced by a more confrontational approach aimed at influencing the societal acceptance of smoking through media campaigns, targeted not only at smokers but also at the public and policymakers, so 
that they would take the issue of second-hand smoke more seriously. The new approach did not shy away from attacking the tobacco industry, or from political lobbying. In 1987, the year that parliament approved the Tobacco Act, STIVORO's lobby concentrated on influencing members of both houses of parliament and government officials through meetings and letters. STIVORO's 1987 annual report summarised the success of these lobbying efforts: "Much of our efforts can be found in parliament's proceedings." However, this did not lead to concrete improvements to the Tobacco Act. While the whole tobacco industry family had been intensively consulted and involved in the drafting of the act, STIVORO and other health organisations were left out.

In the 1980s STIVORO fought an uphill battle against the industry on the passive smoking issue. In 1981 it ran the campaign "Who smokes is not seen," 17 on behalf of the Ministry of Health. The campaign morally supported non-smoking employees who longed for a smoke-free work environment. This reflected the cabinet's wish not to impose regulations but to leave it to employees and employers to work out solutions together. The industry's Stichting Sigaretten Industrie (Cigarette Manufacturers Association) (SSI) complained that STIVORO suggested in the advertisements that smokers endangered the health of non-smokers, and STIVORO was ordered by the Advertising Code Committee, which oversaw the appropriateness of advertisements, to refrain from similar advertising (Board of Appeal, 1982).

STIVORO was not intimidated and in 1984 ran another media campaign with large advertorials in the four main newspapers: "Ten million non-smokers ask for less." 18 The advertisement included an explicit statement that passive smoking is harmful to health. The SSI again filed a complaint, arguing that a causal association between passive smoking and disease had not been proven. The Advertising Code Committee requested STIVORO to refrain from similar statements in the future, but STIVORO refused. A similar complaint in 1985 by SSI and the Vereniging Nederlandse Kerftabakindustrie (Dutch Fine Cut Tobacco Industry Association) (VNK) was declared unfounded, and the industry appealed and won. STIVORO concluded publicly that the committee was not impartial, since members received tobacco industry advertising money.

In 1985 STIVORO published a blacklist summarising the tobacco industry's advertising and tobacco promotion tactics (STIVORO, 1985). Two years later it launched another campaign, "Who will relieve the non-smoker from smoking?" 19 The campaign consisted of newspaper 
advertisements and letters to employers aimed at swinging public opinion towards support for smoking bans, explicitly stating that passive smoking is harmful to health. STIVORO and civil servants from the Ministry of Health regarded this as a crucial campaign, because once it was recognised and broadly accepted that passive smoking is not merely a nuisance but damaging to health, it would open the way to smoking bans in the public domain. The tobacco industry reacted furiously and launched a counter-campaign, "Who will relieve the workplace from a discussion?" casting doubt on the causal link between passive smoking and disease. SSI and VNK filed a successful complaint about STIVORO with the Advertising Code Committee. STIVORO neglected the committee's demand to cease and continued its campaign into 1987 and 1988. The industry, in a collaborative action of 14 tobacco manufacturers, took STIVORO to court, leading to a three-year legal battle that put a strain on STIVORO's resources and challenged the determination of its board. In 1991 STIVORO won the case convincingly, since it could prove that exposure to second-hand smoke does cause disease. However, deterred by the prospect of continued legal battle in a higher court (legal costs had already reached 400,000 guilders, paid by the government), STIVORO's board accepted an offer by the industry to settle the case. Much to their dismay, the industry immediately sent out a misleading press statement claiming victory and proclaiming that "The Court of Justice at The Hague concluded that scientific investigations have not established which facts concerning passive smoking are correct and which are incorrect. The matter is a controversial one and opinions about it differ" (Cigarette shag information bureau, 1991).

In 1991 at a press conference, STIVORO called on the government to support the European Commission's (EC) proposal for a tobacco advertising directive. The director of the Dutch Heart Foundation, who was chair of the European Heart Network at the time, wrote a letter to ministers and parliament, asking them to adopt the advertising ban and arguing that health and wellbeing must prevail above economic interests (Vermaat, 1995). In September 1993 STIVORO's director De Jong visited the leaders of the main factions in parliament to further lobby for the ad ban, and in December STIVORO published a large newspaper advertisement with the title, "Where is our politicians' common sense? Eight million Dutch say 'no' to tobacco advertising." The ad featured a cartoon of a Marlborotype cowboy riding an ostrich with its head in the sand. The three health charities and the newly founded Medical Alliance Against Smoking wrote 
letters to the parliament. At the 9th World Conference on Tobacco or Health in 1994 in Paris, the governments of the Netherlands, the United Kingdom, and Germany were called upon by conference organisers to give up their blocking minority position in the European Union (EU): "Their governments' action in blocking the implementation of the Directive on Tobacco Advertising in the European Union is an international scandal" (Tubiana, 1994).

\section{Boudewijn de Blij (1994-1999)}

STIVORO's director Boudewijn de Blij had experience with Dutch politics in a former position as secretary of the supporting organisation of the Labour Party's faction in the Dutch parliament. He eschewed the confrontational and activist style of De Jong, convinced that it was better to entertain good contacts with representatives from the ministry:

We trusted each other. We collaborated. If they needed a critical letter from us, we immediately produced that. But at the time no one was allowed to know this arrangement. I think that we were calling each other two or three times per week. I wanted to know what was happening at the ministry, or he [his counterpart at the ministry] needed something from me, sometimes just information. ${ }^{20}$

De Blij was successful in securing money from the ministry because he knew exactly when and how to ask for more through his contacts. "I found this much more effective than publicly picking fights with your friends. That is how I did it." 21 A civil servant, when contemplating STIVORO's different directors, commented, "I think Boudewijn manoeuvred most cleverly of all. He operated as much as possible in a low profile manner." 22

De Blij regularly wrote letters to the government to ask for improvements in tobacco control: for example, in 1996 he made a plea to the cabinet to limit tobacco sales to specialty shops and to ban vending machines (Boudewijn De Blij, 1996). He personally wrote amendments to the new Tobacco Act that were put forward by Labour politicians in parliament because "that was my old profession, so I was quite familiar with how to do it." 23

On one occasion De Blij agitated the industry by commissioning a report examining how much money the industry spent on tobacco advertising and 
checking on whether it was correctly paying taxes. This resulted in a remarkable finding: the industry was allowed substantial permanent interest-free sums of money (more than a million euros free to re-invest) because there was a larger time delay then necessary between the delivery of cigarettes to the market and having to pay tax and VAT to the Ministry of Finance (Okkerse, 1997). The report led to media attention, parliamentary questions, proposals from parliament to amend the tobacco taxation law, ${ }^{24}$ and even protests from the tobacco retail sector NSO about unfair treatment of the manufacturers at the cost of the retailers. Although the Ministry of Finance reconsidered its agreement with the industry, not much changed. Nevertheless, a few years later the matter still bothered the industry, which again had to deny that it received "state finance" (Roelofs, 2001).

When Minister Els Borst came into office in 1994, the first tobacco control proposals were not very innovative, especially concerning tobacco advertising. STIVORO intensified its lobby, calling on the new minister to come up with the strongest possible tobacco control programme. When Borst presented her prevention nota to parliament, De Blij wrote her a letter, copied to the minister of economic affairs, remarking that the European Advertising directive was not mentioned in the nota and that Borst must support an EU advertising ban (De Blij, 1995). In addition, the chair of the KNMG wrote a letter to cabinet and parliament urging them to support the ad ban proposal (Lanphen \& van Berkestijn, 1995), and the Dutch Medical Alliance Against Smoking called on the cabinet to regulate tobacco advertising in a petition signed by 185 professors. When the Dutch industry distributed a report highlighting the negative economic consequences of advertising and marketing restrictions (it claimed that 651 jobs would be lost in the marketing and advertising sector), STIVORO quickly replied by commissioning the research firm Science \& Strategy to list the many marketing activities that the industry uses to reach young people (Science \& Strategy, 1996). Other organisations were also rounded up by De Blij to put more pressure on the government. For example, in 1996 the youth organisations of the Christen-Democratisch Appèl (Christian Democratic Party) (CDA), the Green-Left Party, the Labour Party, D66, and the small Christian parties, wrote a long letter to the leaders of their factions in the parliament arguing for an advertising ban (De Poorter, 1996). They gave many examples of how the industry continued to target students (through university magazines and sponsoring activities on campus, for instance), and called on their parties to ban tobacco advertising in addition to increasing taxation levels and reducing the number of tobacco selling points. 
The following year, Borst said she had changed her position regarding tobacco advertising. The new Labour government in the United Kingdom had stopped resisting the ban, releasing the government from a commitment dating back to 1993 to oppose the EU advertising ban as long as the British voted against it (see also Box 6.1). This paved the way for national legislation in the Netherlands. The intensified lobbying for an advertising ban by the national tobacco control coalition led by STIVORO was important, but what ultimately made the difference was the change in the United Kingdom's position, which opened up a window of opportunity for Borst to give the advertising ban its final push.

De Blij did not shy away from direct confrontations with the industry. Inspired by news from the United States that the industry had known for years that tobacco was addictive and had lied about it, De Blij explored the costs and viability of taking the tobacco industry to court in a product liability court case, claiming incurred damage to society because of tobacco use (Geus \& Van der Lee, 1997). However, considering the enormous cost, necessary perseverance, and other constraints on the organisation, STIVORO's board decided against legal action.

\section{Trudy Prins (1999-2006)}

Trudy Prins had a background in public relations at the Ministry of Agriculture. Her biggest distinguishing element was that she used the media as a lobbying tool. Most often she did this in tandem with civil servants at the ministry. Critique through the media on the slow working of the bureaucracy helped her counterparts at the ministry speed things up or come up with stricter regulative proposals than might have been possible without such public attention.

One of Prins's first actions was to have STIVORO organise a lobby campaign to support the governments' intention to increase tobacco taxation in 2004 by at least 10\%. Directors of six national institutes for public health co-signed the letter to the minister of Finance (Prins, 2003). The Ministry of Health simultaneously pleaded with the finance minister to increase taxation for public health reasons. It is unclear how instrumental the lobbying was to this, but in 2004 tobacco taxation increased by $14 \%$.

During Prins' time as director, STIVORO had its biggest success. Prins with help from STIVORO's network succeeded in securing majority support in parliament for an amendment by the Green-Left party to include the workplace smoking ban in the new Tobacco Act in 2002. Part of the 
reason for Prins' success was that STIVORO, together with CAN and the Lung Foundation, had supported post office employee Nanny Nooijen about her right to work in a smoke-free environment. The fact that Nanny Nooijen won her case convincingly was important in encouraging politicians to support the ban.

With Health Minister Els Borst the government was committed to stronger tobacco control STIVORO was given an important role in executing the governments' tobacco control agenda, and the organisation grew considerably to handle its new tasks. STIVORO transformed into a national expert centre on tobacco education and cessation support, with a staff fully dedicated to developing evidence-based education, cessation interventions, and campaigns. These were STIVORO's 'golden years'.

\section{Lies van Gennip (2006-2012)}

At the time that Lies van Gennip, a biologist with a $\mathrm{PhD}$ and management experience in health research organisations, began working as director of STIVORO, the three charities were reconsidering their relationship with STIVORO and were already experimenting with their own tobacco control activities. The governing board of STIVORO was replaced by a board of trustees and the health ministry no longer had a seat on the board. STIVORO was given the task of executing the NPT programme and the charities began to make STIVORO more accountable for the money they spent on tobacco control. Van Gennip was charged with the task of reorganising the organisation and making STIVORO more efficient and accountable.

At the request of the charities, STIVORO hired Van Oort \& Van Oort Public Affairs, a professional lobbying firm, to support advocacy activities. At that time the third Balkenende cabinet had just fallen, and new elections were called. Van Oort organised a broad lobby to get three goals into party programmes and into the coalition agreement: a smoke-free hospitality sector, a tax increase, and reimbursement of smoking cessation support. In a few months STIVORO was able to secure support from 40 societal and medical organisations around one united call for political commitment to a smoke-free hospitality sector. In addition, it supported CAN to initiate the first civil society initiative to get smoke-free bars and restaurants on the political agenda, by helping CAN collect 62,000 signatures.

In 2007, when the smoking ban in the hospitality sector was to be discussed in the cabinet, van Gennip sent a letter to Prime Minister 
Balkenende with arguments as to why a smoking ban was good for public health (Van Gennip, 2007). The letter was accompanied by a DVD featuring interviews with experts from several European countries, all of whom testified to the successes and positive experiences with similar bans in their home countries. The lobbying effort was successful, and the introductory dossier for the new minister of health listed all three goals (Bekker, 2007), and a smoke-free hospitality sector was included in the coalition agreement of the fourth Balkenende cabinet to fast track the smoking ban in bars and restaurants. Van Gennip and the directors of the three charities met with the new Health Minister Ab Klink, but this did not result in further commitments from the government to initiate new tobacco control measures (Rutgers, Hanselaar, Stam, \& Van Gennip, 2007). The clumsy and ambiguous implementation of the smoking ban in cafés by Minister Klink unleashed an unprecedentedly aggressive response by groups and individuals who regarded the ban as an infringement on individual liberties. They took their anger out on STIVORO, which was confronted by angry smokers, sometimes fuelled by organisations such as pro-smokers group Forces and the smokers' rights group Stichting Rokers Belangen (SRB), but also from anonymous sources on the internet.

Gradually the unwillingness of the government to take further action on tobacco control, coupled with the determination of Lies van Gennip to obtain results, led to polarisation and a hostile atmosphere. The charities were not comfortable with this because it jeopardised the relationship they enjoyed with the government. As a lobbyist from one of the charities said, "We were very much bothered by the unpleasant and harsh tone of voice that STIVORO was using. As a result, the government was closing its doors to us." ${ }^{25}$

STIVORO's successes and the tight connections between STIVORO and the tobacco control officers at the health ministry did not go unnoticed. According to an ex-civil-servant:

The industry was horrified by all this ... Eventually with other ministers, with another political winds of change, it began to affect STIVORO. I belief that STIVORO was ultimately judged on this; the questions that were raised in parliament by MP Schippers... At a certain moment it also began to vibrate within the ministry, especially under 'minister] Klink: STIVORO was no longer allowed to run campaigns ... STIVORO began to be seen as patronising and as the 'anti's'. ${ }^{26}$ 
In May 2009 Van Gennip received a phone call from the industry's VNK with the threat that if STIVORO continued its assertive lobbying, VNK would use its influence at the ministry through VNO-NCW to make sure that STIVORO was harmed. Soon afterwards a civil servant from the Ministry of Health told STIVORO's director that it must cease advocacy activities because STIVORO was losing its support from the ministry. A month after the threat from VNK, in June 2009, STIVORO received a letter from the ministry that its yearly subsidy would be cut.

One example of the intensive lobbying activities that STIVORO was capable of during this time were letters delivered personally to the officials responsible for forming a new ruling coalition in July 2010 (Bensing, Brand, \& Borst, 2010). The letter was co-signed by 34 national and international experts, and informed the officials that the previous government had invested too little in tobacco control, causing a stagnation of the decline in smoking prevalence rates, and that they advised the new government to adopt a tobacco control policy based on three pillars: a substantial tobacco tax increase, allocation of the revenues to more education, and making the denormalisation of tobacco use a central issue.

When Health Minister Schippers entered the arena in 2010 and tobacco control was reversed, STIVORO fired up its advocacy activities while fighting for its own survival-a move that distanced it even more from the three charities. STIVORO tried to win an increasingly lost cause by continuing the strategy of presenting facts and science against ideology, using the public health frame to emphasise tobacco's deathly effects. For example, it launched a website where statements by Schippers about tobacco and tobacco policy were rebutted. The website was introduced with these lines:

Every year tens of thousands of people die because of smoking. Smoking is the number one cause of death in the Netherlands. One in two dies from its addiction. It is harsh to put it this way, but it is a policy choice. Choosing for no policy or a minimal policy is choosing for these numbers. That is what this website is about.

STIVORO was determined to fight the reversal of the smoking ban and to push for a California-inspired activist model: "clearly, the challenge for the public health community is to stand firm and continue to press for the successful model already working so well in many other countries. Where 
the protection of non-smokers is at stake, "going Dutch" is simply not an option" (Van Bladeren, 2011). But by now STIVORO's cause was lost, for it had lost its support from the charities, which wanted to re-organise tobacco control advocacy and take the lead themselves.

\section{CONCLUSION}

The Dutch tobacco control coalition was organised in a unique way. The core of the advocacy network consisted of the three charities that financed STIVORO to fight smoking on their behalf, while the Ministry of Health was also on the board of the organisation. The organisations were united in a joint fight against the tobacco industry. The arrangement was typically Dutch: compromises between government and civil society were locked into the fabric of the organisation of STIVORO. For many years this worked well: especially under Minister Els Borst, the relationship between STIVORO and the tobacco control unit at the Ministry of Health was very good and mutually reinforcing, and STIVORO was allowed to prosper and grow into an internationally acclaimed tobacco control expert centre, while ever-increasing subsidies from the government and occasional large donations from the charities made it possible to organise largescale smoking cessation media events that motivated many smokers to quit smoking. The flip side was that, since the government was accountable for STIVORO's activities to parliament, the tobacco control coalition was unable to set up a professional lobbying apparatus. Professional lobbying was not integrated into the overall action plans of the organisation until around 2006, when a professional lobbying firm was hired to coordinate advocacy activities.

Over time the tobacco control coalition expanded, in the mid-1990s through the Dutch Medical Alliance Against Smoking and at the beginning of the 2000s through the Partnership Stop Smoking. Despite the fact that this strengthened the coalition's advocacy capacity, help from the broader medical community did not materialise in the Netherlands as it did in the United Kingdom, where medical organisations were key to cultivating a social climate more conducive to tobacco control while putting pressure on ministers to take the smoking problem more seriously.

During periods when the government opposed or delayed tobacco control, the lobby led by STIVORO was more assertive towards the government. This happened in the 1980s and beginning of the 1990s (Van Agt and Lubbers cabinets), and between 2007 and 2012 when Klink and 
Schippers were ministers of Health. During periods when the government showed more willingness to control tobacco, the collaboration with STIVORO relaxed. The tobacco control coalition had several important lobbying successes. Most important probably was its support of the small understaffed tobacco control unit at the ministry of health leading up to the revised Tobacco Act. Notable was the inclusion of the important workplace smoking ban in the revised Tobacco Act, which was a direct result of coordinated lobbying of parliamentarians by STIVORO. In 2007, STIVORO was successful in pushing the government to extend the workplace smoking ban to bars and restaurants, but it failed to prevent the tobacco lobby from sabotaging the implementation, leading to a temporary reversal of the ban.

Around 2005 a major shift took place in the Dutch tobacco control coalition when the three charities were no longer willing to play second fiddle and wanted a more proactive tobacco control advocacy role. However, it took another 8 years before STIVORO, which had been the central tobacco control organisation since 1975, was disbanded, during which time the three charities gradually increased and professionalised tobacco control advocacy.

\section{Notes}

1. "Coalition" is used here in terms of the Advocacy Coalition Framework.

2. The three big charities in the United States built the "Coalition on Smoking OR Health," in which lobbyists from the charities worked together under a single coordinator, independent from the government (Derthick, 2005).

3. Parliamentary Papers II, 1977-1978, 14,800, XVIII, nr. 34.

4. Proceeding, II 1976-1977, 14,360, nr. 2.

5. About $€ 910,000$ at current monetary value.

6. This was not a typical Dutch concern at the time. For example, in the United States, the health charities faced similar constraints. They felt that they needed to protect their image as a mainstream, legitimate organisation, which limited the way they could lobby openly for controversial goals (Wolfson, 2001).

7. Proceedings I, 26 March 2002, EK 24-1263.

8. Proceedings II, 24 June 1987, 91-4639.

9. Interview on 16 June 2016.

10. Source: STIVORO's annual reports.

11. Interview on 20 October 2015. 
12. Interview on 29 October 2015. The current size of the core team is three officials: one team leader (who may also be responsible for other issues), and two officers-one responsible for international-level tobacco policy and one for national-level tobacco policy. It is supported by trainees or officials from "flex pools."

13. Interview on 16 April 2016.

14. Interview on 26 April 2016.

15. Proceedings II, 9 December 1993, 36-2773.

16. Interview with a former civil servant on 6 October 2015.

17. In Dutch: "Wie rookt is niet gezien."

18. In Dutch: "10 miljoen niet-rokers vragen of het wat minder kan."

19. In Dutch: "Wie helpt de roker van het roken af?"

20. Interview 17 June 2016.

21. Interview 17 June 2016.

22. Interview 26 April 2016.

23. Interview 17 June 2016.

24. Tweede Kamer, 2000-2001, 26,472, nr. 23.

25. Interview on 15 March 2017.

26. Interview, 6 November 2015.

\section{ReFERENCES}

Adriaanse, H., Van Reek, J., \& Metsemakers, J. (1986). Smoking behaviour of Dutch general practitioners in the period 1977-1983. Scandinavian Journal of Primary Health Care, 4, 151-156.

Adriaanse, H., Van Reek, J., \& Van Zutphen, W. (1986). Rookgewoonten van artsen wereldwijd: Een overzicht van 100 onderzoekingen naar tabaksgebruik onder artsen in 31 landen in de periode 1951-1985. Nederlands Tijdschrift voor Geneeskunde, 130, 2224-2229.

Baan, B. (1986). Strategieen ter bevordering van het niet-roken. Nederlands Tijdschrift voor Geneeskunde, 130, 1232-1139.

Barneveld, J. T. A., Dalesio, O. B., \& Van Leeuwen, F. E. (1992). Een ontmoedigend tabaksontmoedigingsbeleid: Pleidooi voor een integrale aanpak. Medisch Contact, 47, 943-944.

Beernink, J. F., \& Plokker, J. H. (1975). Maatregelen tot beperking van het roken. Advies van de Gezondheidsraad. Verslagen, Adviezen, Rapporten (Vol. 23). Leidschendam: Ministerie van Volksgezondheid en Milieuhygiëne.

Bekker, R. (2007). Introductiedossier nieuwe bewindspersonen Ministeries van VWS. Den Haag: VWS.

Bensing, J., Brand, P., \& Borst, E. (2010). Brief aan de informateurs [letter to the inquirers]. Retrieved from http://www.ggdghor.nl/media/filebank/557bea2 639e542e8843db5db9797445c/stivorobrief.pdf 
BMA. (1986). Smoking out the barons: The campaign against the tobacco industry. A report of the British Medical Association Public Affairs Division. Chichester: Wiley \& Sons.

Board of Appeal. (1982). Decision in the case of Dijkstra/Public Health and Smoking Foundation. Dutch Tobacco Industry Collection, Bates No. JB1457. Retrieved from https://www.industrydocumentslibrary.ucsf.edu/tobacco/ docs/\#id=zkgp0219

Boucher, P. (2000). Rendez-vous with Trudy Prins. Retrieved from http:// archive.tobacco.org/News/rendezvous/prins.html

Bouma, J. (2000). Echo's uit de prairie. Dossiers Onderzoeksjournalistiek. Retrieved 29 July, 2017, from https://www.villamedia.nl/journalist/n/dossiers/onderzoekphilipmorris.shtm

Bouma, J. (2001). Het rookgordijn: De macht van de Nederlandse tabaksindustrie. Amsterdam: Veen.

Chapman, S. (2017). Why researchers have a duty to try and influence policy. Retrieved from The Conversation website: https://theconversation.com/ why-researchers-have-a-duty-to-try-and-influence-policy-71081

Cigarette shag information bureau. (1991). STIVORO trial ended: Tobacco Industry satisfied with court verdict. Dutch Tobacco Industry Collection, Bates No. JB1025. Retrieved from https://www.industrydocumentslibrary.ucsf. edu/tobacco/docs/xqfp0219

De Blij, B. (1995). [Brieven van Stivoro aan de ministeries van EZ en VWS]. Dutch Tobacco Industry Collection, Bates No. JB2574. Retrieved from https:// www.industrydocumentslibrary.ucsf.edu/tobacco/docs/nlwp0219

De Blij, B. (1996). Amendement Tabaksaccijns. Dutch Tobacco Industry Collection, Bates No. JB2691. Retrieved from https://www.industrydocumentslibrary. ucsf.edu/tobacco/docs/tqwp0219

De Jong, R. (1984). Commentaar op de ontwerp tabakswet [letter]. Dutch Tobacco Industry Collection, Bates No. JB2104. Retrieved from https://www.industrydocumentslibrary.ucsf.edu/tobacco/docs/hpfp0219

De Jong, R. (1989). Notitie met het oog op de uitvoering van het meerjaren voorlichtingsprogramma niet-roken. Dutch Tobacco Industry Collection, Bates No. JB1425. Retrieved from https://www.industrydocumentslibrary.ucsf. edu/tobacco/docs/kzhp0219

De Jong, R., \& Nelissen, J. G. M. (1984). [Brief van Stivoro aan de voorzitter en Leden der Staten-Generaal]. Dutch Tobacco Industry Collection, Bates No. JB2305. Retrieved from https://www.industrydocumentslibrary.ucsf.edu/ tobacco/docs/mpdp0219

De Poorter, J.-P. (1996). [Brief van de Nationale Jongerenraad voor Milieu en Ontwikkeling aad de Tweede kamer fractie van CDA]. Dutch Tobacco Industry Collection, Bates No. JB1948. Retrieved from https://www.industrydocumentslibrary.ucsf.edu/tobacco/docs/jjbp0219 
Dekker, E. (1981). De huisarts en het rookpatroon. In STIVORO (Ed.), Trekt de rook langzaam op? Voordrachten van het symposium. Den Haag: STIVORO.

Derthick, M. A. (2005). Up in smoke: From legislation to litigation in tobacco politics (2nd ed.). Washington, DC: CQ Press.

Dresscher, I., Elzinga, A., \& Koldenhof, E. (1991). Evaluatie tabakswet en zelfregulering tabaksreclame. Zoetermeer: Research voor Beleid.

Duivenvoorden, E. (2009). Magiër van een nieuwe tijd: Het leven van Robert Jasper Grootveld. Amsterdam: De Arbeiderspers.

Geus, M., \& Van der Lee, J. (1997). STIVORO/Produktaansprakelijkheid. Dutch Tobacco Industry Collection, Bates No. JB1011. Retrieved from https://www. industrydocumentslibrary.ucsf.edu/tobacco/docs/ftcp0219

Hilvering, C., Knol, K., \& Wagener, D. J. (1995). Petitie tot strenge beperking tabaksreclame. Dutch Tobacco Industry Collection, Bates No. JB2550. Retrieved from https://www.industrydocumentslibrary.ucsf.edu/tobacco/docs/gggp0219

Hoogervorst, H., Zoun, J. P. M., De Blij, B. A. J. M., \& Hanselaar, A. G. J. M. (2005). Intentieverklaring tabaksontmoediging. Dutch Tobacco Industry Collection, Bates No. JB3189. Retrieved from https://www.industrydocumentslibrary.ucsf.edu/tobacco/docs/kgdn0217

ITC Project. (2010). The International Tobacco Control Policy Evaluation Project: ITC Netherlands National Report. Ontario, The Hague: ITC Project, University of Waterloo, Canada.

Joossens, L., \& Raw, M. (2011). The tobacco control scale 2010 in Europe. Brussels: Association of European Cancer Leagues.

KNMG. (2007). Volksgezondheid en Preventie De visie van de KNMG. Utrecht: KNMG.

KNMG. (2016). Tobacco discouragement: Towards a smoke-free society. Utrecht: Royal Dutch Medical Association.

Knol, K. (1995, January 11). Kinderen doelwit van tabaksreclame. Trouw. Retrieved August 19, 2017, from http://www.trouw.nl/tr/nl/5009/Archief/ article/detail/2663243/1995/01/11/Kinderen-doelwit-van-tabaksreclame. dhtml

Knol, K. (1996a). [Brief van Knol aan Borst]. Dutch Tobacco Industry Collection, Bates No. JB1947. Retrieved from https://www.industrydocumentslibrary. ucsf.edu/tobacco/docs/ytvp0219

Knol, K. (1996b). Medische Alliantie tegen het roken. Dutch Tobacco Industry Collection, Bates No. JB2673. Retrieved from https://www.industrydocumentslibrary.ucsf.edu/tobacco/docs/spwp0219

Knol, K. (1997). De toekomst van de strijd tegen het roken. Medisch Contact, $52(25), 803-804$.

Lanphen, J.M.G., \& Van Berkestijn, Th.M.G. (1995). [Brief van de Koninklijke Nederlandse Maatschappij tot Bevordering de Geneeskunst aan de leden van het Kabint en de leden vande Tweede Kamer der Staten Generaal]. Dutch Tobacco Industry, Bates No. 2057. Retrieved from https://www.industrydocumentslibrary.ucsf.edu/tobacco/docs/lxdp0219 
Mackenbach, J. P. (2006). Antirookbeleid moet anders. Medisch Contact, 13, 512-514.

Mackenbach, J. P. (2009). Echte minister van Gezondheid gezocht. Volkskrant.

Mackenbach, J. P. (2016). Nederland rookvrij: dokters spreken zich uit: $\mathrm{Nu}$ de politiek nog. Nederlands Tijdschrift voor Geneeskunde, 160, D310.

Mackenbach, J. P., Klazinga, N. S., \& Van der wal, G. (2004). Preventie vraagt ambitieuzere aanpak. Reactie op de kabinetsnota 'Langer gezond leven 2004-2007; ook een kwestie van gezond gedrag. Nederlands Tijdschrift voor Geneeskunde, 148(15), 704-707.

Meinsma, L. (1969). Roken en risico's. Lochem: De Tijdstroom.

Mudde, A. N., \& De Vries, H. (1999). The reach and effectiveness of a national mass media-led smoking cessation campaign in the Netherlands. American Journal of Public Health, 89(3), 346-350. https://doi.org/10.2105/ AJPH.89.3.346

Nagelhout, G. E., Willemsen, M. C., van den Putte, B., Crone, M., \& de Vries, H. (2009). Evaluatie 'in iedere roker zit een stopper' campagne: tweede nameting. Den Haag: STIVORO.

Okkerse, W. D. (1997). De sigarettenindustrie in Nederland: Uit (de) Balans? Rijswijk: ITLC Associate.

Op de Weegh, J. M. J., \& Willemsen, M. C. (2003). Dat Kan Ik Ook!: De stoppen met roken millenniumcampagne. Den Haag: STIVORO.

Partnership Stop met Roken. (2004). Beleidsaanbevelingen voor de behandeling van tabaksverslaving. Den Haag: Partnership Stop met Roken.

Prins, G. J. J. (2003). Verhoging tabaksaccijns. Dutch Tobacco Industry Collection, Bates No. JB0600. Retrieved from https://www.industrydocumentslibrary. ucsf.edu/tobacco/docs/mmxb0191

Rathjen, H. (1999). The coalition. How to build a coalition in connection with a public health campaign to obtain tobacco control measures. Quebec: Coalition Québécoise pur le contrôle du tabac.

Rijksen, W. (2005). Evaluatie van het tabaksontmoedigingsbeleid [letter KNMG]. Dutch Tobacco Industry Collection, Bates No. JB2971. Retrieved from https:// www.industrydocumentslibrary.ucsf.edu/tobacco/docs/qsdn0217

RJ Reynolds. (1979). Summary of the PR Program of the Dutch Cigarette Manufactures Association. RJ Reynolds Records, Bates No. 500877429-500877431. Retrieved from https://www.industrydocumentslibrary.ucsf.edu/tobacco/docs/jrpj0096

Roelofs, W. J. (2001). Accijnskrediet. Dutch Tobacco Industry Collection, Bates No. JB1755. Retrieved from https://www.industrydocumentslibrary.ucsf. edu/tobacco/docs/xkcp0219

Roscam Abbing, E. W. (1992). Tabaksbeleid: rookgordijn voor massamoord. Medisch Contact, 47, 931.

Royal College of Physicians. (1962). Smoking and health. London: Royal College of Physicians of London. 
Rutgers, M., Hanselaar, T., Stam, H., \& Van Gennip, L. (2007). Letters to Klink. Dutch Tobacco Industry Collection, Bates No. JB0455. Retrieved from https:// www.industrydocumentslibrary.ucsf.edu/tobacco/docs/rzhb0191

Science \& Strategy. (1996). Inventaristatie van de martketingactiviteiten van de tabaksindustrie. Dutch Tobacco Industry Collection, Bates No. JB1537. Retrieved from https://www.industrydocumentslibrary.ucsf.edu/tobacco/ docs/jmbp0219

SNK \& SSI. (1985). Jaaroverzicht 1984. Dutch Tobacco Industry Collection, Bates No. JB2269. Retrieved from https://www.industrydocumentslibrary.ucsf. edu/tobacco/docs/yfgp0219

SRJ. (2017). Smokers bring case against the tobacco industry. Retrieved from http://www.stichtingrookpreventiejeugd.nl/over-rookpreventie-jeugd/english/item/86-smokers-bring-case-against-the-tobacco-industry

STIVORO. (1978). Een gulden per jaar: Beleidslijnen van de Stichting Volksgezondheid en Roken. Den Haag: STIVORO.

STIVORO. (1985). Reclame als pacemaker van de tabaksindustrie. Den Haag: STIVORO.

STIVORO. (2007). 7,4 miljoen te weinig om gewenste daling rokers te halen [press release 9 januari 2007]. In STIVORO (Ed.). Den Haag: STIVORO.

STIVORO. (2009). Terugblik 2008 [Year report]. Den Haag: STIVORO.

STIVORO. (2010a). Tabaksontmoediging moet anders [newsletter] STIVORO. $n l$ (Vol. 14). Den Haag: STIVORO.

STIVORO. (2010b). Van onderop en van bovenaf: De toekomst van tabaksontmoediging in Nederland 2011-2020. Den Haag: STIVORO.

Tubiana, M. (1994). [Letter from Tubiana to Borst-Eilers and Prime Minister Kok]. Dutch Tobacco Industry Collection, Bates No. JB2584. Retrieved from https://www.industrydocumentslibrary.ucsf.edu/tobacco/docs/hphp0219

Unknown (Philip Morris). (1979). Smoking \& health-Five year plan, Bates No 2501020542-2501020686. Truth Tobacco Industry Documents.

Van Bladeren, F. (2011). Netherlands: Going backwards [news analysis]. Tobacco Control, 20, 4-7.

Van den Putte, S. J. H. M., Yzer, M. C., Ten Berg, B. M., \& Steeveld, R. M. A. (2005). Nederland start met stoppen/Nederland gaat door met stoppen. Evaluatie van de STIVORO campagnes rondom de jaarwisseling 2003-2004. Amsterdam: Universiteit van Amsterdam, ASCOR.

Van Emst, A. J., \& Willemsen, M. C. (2011). Naar een nieuwe structuur voor tabaksontmoediging in Nederland: Verslag van een inspirational conference. Den Haag: STIVORO.

Van Es, J. (1987). Roken. Medisch Contact, 42, 259.

Van Gennip, E. M. S. J. (2007). Brief STIVORO aan Ministerie van Algemene Zaken over beleidsvoornemen om de horeca-rookvrij te maken. Dutch Tobacco Industry Collection, Bates No. JB0344. Retrieved from https://www.industrydocumentslibrary.ucsf.edu/tobacco/docs/snhb0191 
Vandenbroucke, J. P., Kok, J. F. J., Matroos, A., \& Dekker, E. (1981). Rookgewoonten van Nederlandse huisartsen vergeleken met die van de bevolking. Nederlands Tijdschrift voor Geneeskunde, 125(1), 406.

Vermaat, H. (1995). Een piece de résistance: De tabaksreclame en de lobby van de Nederlandse hartstichting voor een verbod (Doctoral thesis), Vrije Universiteit Amsterdam.

Westerik, H., \& Van der Rijt, G. A. J. (2001). De millenniumcampagne 'Stoppen met roken 2000': Evaluatie van een campagne onder Nederlandse rokers. Nijmegen: Katholieke Universiteit Nijmegen.

Willemsen, M. C. (2011). Roken in Nederland: De keerzijde van tolerantie [inaugural lecture]. Maastricht: Maastricht University.

Willemsen, M. C. (2012). Pak de tabakslobby keihard aan. de Volkskrant, 31.

Willemsen, M. C., De Vries, H., \& Van Schayck, O. (2009). Wat ging er mis met rookverbod in de horeca? [Why only the Dutch resist the smoking ban?]. NRC Handelsblad.

Willemsen, M. C., van Kann, D., \& Jansen, E. (2012). Stoppen met roken: ontwikkeling, implementatie en evaluatie van een massamediale campagne. In J. Brug, P. v. Assema, \& L. Lechner (Eds.), Gezondheidsvoorlichting en gedragsverandering. Assen: Van Gorcum.

Wolfson, M. (2001). The fight against big tobacco: The movement, the state, and the public's health. New York: Aldine de Gruyter.

Youth Smoking Prevention Foundation. (2014). Five years of action for a smokefree country. Amsterdam: Youth Smoking Prevention Foundation.

Open Access This chapter is licensed under the terms of the Creative Commons Attribution 4.0 International License (http://creativecommons.org/licenses/ by $/ 4.0 /$ ), which permits use, sharing, adaptation, distribution and reproduction in any medium or format, as long as you give appropriate credit to the original author(s) and the source, provide a link to the Creative Commons license and indicate if changes were made.

The images or other third party material in this chapter are included in the chapter's Creative Commons license, unless indicated otherwise in a credit line to the material. If material is not included in the chapter's Creative Commons license and your intended use is not permitted by statutory regulation or exceeds the permitted use, you will need to obtain permission directly from the copyright holder.

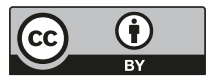

